\title{
Non-marine invasive gastropods on Ilha Grande (Angra dos Reis, Rio de Janeiro, Brazil): distribution and implications for conservation
}

\author{
Jaqueline L. de Oliveira ${ }^{1}$, Igor C. Miyahira ${ }^{1,2}$, Isabela Cristina B. Gonçalves ${ }^{1}$, Renata F. Ximenes ${ }^{1}$, Luiz
}

Eduardo M. de Lacerda ${ }^{1}$, Patrícia S. C. da Silva ${ }^{1}$, Francielle C. Fonseca ${ }^{1}$, Amilcar B. Barbosa ${ }^{1}$, Gleisse Kelly

M. Nunes ${ }^{1,3}$ \& Sonia B. dos Santos ${ }^{1,4}$

${ }^{1}$ Universidade do Estado do Rio de Janeiro, Laboratório de Malacologia Límnica e Terrestre, Rua São Francisco Xavier, 524, Maracanã, Pavilhão Haroldo Lisboa da Cunha, 20550-900, Rio de Janeiro, RJ, Brasil.

${ }^{2}$ Universidade Federal do Estado do Rio de Janeiro, Instituto de Biociências, Departamento de Zoologia, Programa de Pós-Graduação em Biodiversidade Neotropical, Avenida Pasteur, 458, Urca, 22290-240, Rio de Janeiro, RJ, Brasil.

${ }^{3}$ Fundação Oswaldo Cruz, Escola Nacional de Saúde Pública Sergio Arouca, Laboratório de Paleoparasitologia e Ecologia Gustavo de Oliveira Castro, Rua Leopoldo Bulhões, 1480, Manguinhos, 21041-210, Rio de Janeiro, RJ, Brasil.

${ }^{4}$ Universidade do Estado do Rio de Janeiro, Programa de Pós-Graduação em Ecologia e Evolução, Rua São Francisco Xavier 524, Maracanã, Pavilhão Haroldo Lisboa da Cunha, 20550-900, Rio de Janeiro, RJ, Brasil.

*Corresponding author: Igor C. Miyahira,icmiyahira@yahoo.com.br

OLIVEIRA, J.L., MIYAHIRA, I.C., GONÇALVES, C.B., XIMENES, R.F., LACERDA, L.E.M., SILVA, P.S.C., FONSECA, F.C., BARBOSA, A.B., NUNES, G.K.M., SANTOS, S.B. Non-marine invasive gastropods on Ilha Grande (Angra dos Reis, Rio de Janeiro, Brazil): distribution and implications for conservation. Biota Neotropica 20(3): e20201060. https://doi.org/10.1590/1676-0611-BN-2020-1060.

Abstract: Invasive species are one of the main causes of biodiversity loss and the knowledge of their distribution is essential for conservation efforts. The present study inventoried the land and freshwater invasive molluscs of 25 villages of Ilha Grande (Rio de Janeiro, Brazil), an island with Atlantic Rainforest remnants. Three invasive species are found: Melanoides tuberculata (Müller, 1774), Physa acuta Draparnaud, 1805, both on two localities; and Achatina fulica Bowdich, 1822, on 16 localities. Most records were done on the island continental side, in anthropic areas, probably due to ease of access. One record was inside a conservation area, that calls concern about the spread of those species on the island and possible effects.

Keywords: Achatina fulica, Melanoides tuberculata, Physa acuta, non-native species, Gastropoda.

\section{Moluscos continentais invasores na Ilha Grande (Angra dos Reis, Rio de Janeiro, Brasil): distribuição e implicação para a conservação}

Resumo: As espécies invasoras são uma das maiores causas de perda de biodiversidade e o conhecimento acerca da sua distribuição é essencial para os esforços de conservação. O presente estudo inventariou os moluscos continentais invasores em 25 vilas da Ilha Grande (Rio de Janeiro, Brasil), uma ilha com remanescentes de Mata Atlântica. Três espécies invasoras foram encontradas: Melanoides tuberculata (Müller, 1774), Physa acuta Draparnaud, 1805, ambas em duas localidades; e Achatina fulica Bowdich, 1822, em 16 localidades. A maior parte dos registros foi no lado continental da ilha, provavelmente devido a facilidade de acesso. Um dos registros foi dentro de uma área de conservação, o que chama a atenção para a dispersão destas espécies na ilha, e seus possíveis efeitos.

Palavras-chave: Achatina fulica, Melanoides tuberculata, Physa acuta, espécies não-nativas, Gastropoda. 


\section{Introduction}

The impact of non-native species on ecosystems is well discussed (e.g. Lockwood et al. 2005, Pimentel et al. 2005, Boltovskoy 2017, Cowie et al. 2017), especially on an insular system (Cowie 1998, Clavero \& García-Berthou 2005, Pyšek et al. 2017). Some of these species, as Achatina fulica Bowdich, 1822, and Melanoides tuberculata (Müller, 1774), are dispersed worldwide, offering a combination of environmental, economic, and health concerns (GraeffTeixeira 2007, Santos et al. 2012).

The African giant snail was introduced in Brazil around 1980 for commercial purposes and nowadays is widespread (Thiengo et al. 2007, Colley \& Fischer 2009). This species is hermaphrodite, and a single specimen can initiate a new population, as autofecundation is possible (Thiengo et al. 2007, Fischer \& Colley 2005). Achatina fulica can cause not only environmental problems, like the competition with native species, as Megalobulimus spp. (Gutiérrez-Gregoric et al. 2011), but also questions related to public health (Thiengo et al. 2007, GraeffTeixeira 2007). Achatina fulica is the intermediate host for nematodes of medical and veterinary importance like Angiostrongylus costaricensis (Morera \& Céspedes, 1971), Angiostrongylus cantonensis (Chen, 1935), Aelurostrongylus abstrusus (Railliet, 1898), Rhabditis sp. and Strongyluris sp. (Vicente et al. 1993, Thiengo et al. 2008, 2010, Oliveira et al. 2010).

The Afro-Asiatic freshwater snail M. tuberculata was introduced in Brazil around 1967, in Santos, São Paulo state, probably by aquarium trade (Vaz et al. 1986). Nowadays it is widespread in Brazil (Fernandez et al. 2003, Santos et al. 2012, Miyahira et al. 2020). Melanoides tuberculata is parthenogenetic and resistant to desiccation (Facon et al. 2004; Weir \& Salice 2012), two features that probably helped this species to disperse so widely. This species is the intermediate host of several trematodes, including Centrocestus formosanus (Nishigori, 1924) and Philophthalmus gralli Mathis \& Leger, 1910 (Pinto \& Melo 2011, Ximenes et al. 2017). There are no autochthonous human cases of these parasites described to Brazil, although it was already recorded in oriental immigrants, living in São Paulo city, infected with Clonorchis sinensis (Cobbold, 1875) (Leite et al. 1989).

Physa acuta is an invasive freshwater gastropod worldwide distributed (Paraense \& Pointier 2003, Taylor 2003). The first record on Brazil was in 1966, under the name Physa (Physella) cubensis Pfeiffer, 1839 (Leme 1966), but nowadays it is widespread especially in southeastern Brazil (Santos et al. 2012) and some records in the states of Bahia and Goiás (Santos et al. 2016). This species is hermaphrodite and recognized for some environmental impacts (Taylor 2003, Zukowski \& Walker 2009).

Ilha Grande is one of the largest insular remains of the Atlantic Rainforest in Brazil, and place of four conservation areas: Ilha Grande State Park, Praia do Sul Biological Reserve, Aventureiro Marine State Park, and Tamoios Ambiental Protection Area. The first two include almost all terrestrial surface of the island, except for most villages, that are included in Tamoios Ambiental Protection Area.

Those three invasive species were already recorded for Ilha Grande: Achatina fulica was first mentioned in 2002 (Santos et al. 2002), M. tuberculata in 2005 (Santos et al. 2007), and P. acuta in 2009 (Miyahira et al. 2010) to the main village of Ilha Grande, Vila do Abraão. However, the distribution of these species on the island is unknown. The main goal of this study was to present the distribution of these species on Ilha Grande, as also some observations on conservation issues, as the first step for future managing, conservation, and educational plans.

\section{Material and Methods}

Ilha Grande $\left(23^{\circ} 05^{\prime}, 23^{\circ} 15^{\prime} \mathrm{S}\right.$ and $\left.44^{\circ} 06^{\prime}, 44^{\circ} 23^{\prime} \mathrm{W}\right)$, is an island located on the southern coast of the Rio de Janeiro state, southeast Brazil, far from $150 \mathrm{~km}$ from the city of Rio de Janeiro, in the municipality of Angra dos Reis. The island is covered with important remnants of Atlantic Forest especially on highlands (Callado et al. 2009), but near the coast, the habitats are modified by deforestation, non-native plants, domestic animals, and domestic sewage (Santos et al. 2007). The island can be divided into two sides, one facing the mainland (Continental or North side), with the most villages; and the other facing the open ocean (Oceanic or South side) with fewer villages and more difficult access by boats or trails.

Twenty-five localities were surveyed for invasive snails, were included the villages and nearby areas (anthropic and perianthropic). The localities were reached by trails or boats. Each locality was visited at least twice, and the search for the snails was done by three people at all kinds of suitable habitats. For A. fulica we did a visual inspection on walls, plants, under vegetation debris, and garbage for 30 minutes/ person. Melanoides tuberculata and P. acuta were searched using a handled metallic scoop in freshwater streams for 30 minutes/person. At each village were recorded the "presence" or "absence" regarding the occurrence of the target invasive species: A. fulica, M. tuberculata, and $P$. acuta. All collecting stations were georeferenced using a Garmin Etrex. Samples of live molluscs were placed in plastic bags or pots and took back to the laboratory for biological observations, taxonomic identification, and further parasitological studies.

Voucher specimens are housed at the Malacological Collection of the Universidade do Estado do Rio de Janeiro (UERJ).

\section{Results}

Sixteen localities of Ilha Grande present at least one invasive mollusc species: M. tuberculata, P. acuta, or A. fulica (Figure 1 and Table 1). In most localities only $A$. fulica was found; in Praia Vermelha, two species were recorded (M. tuberculata and P. acuta), and on Vila do Abraão, all the three species occurs. There are only two villages with invasive species on the oceanic side (Provetá and Vila Dois Rios), and 14 on the continental side (Figure 1 and Table 1). All the records of freshwater invasive molluscs were on the continental side, on only two villages (Vila do Abraão and Praia Vermelha). Achatina fulica has distributed along 16 (64\%) villages: 14 on the continental side and two on the oceanic side. Achatina fulica was found colonizing not only the urban environments but also the surroundings of the villages in areas of secondary Atlantic Forest. The two freshwater invasive gastropods were found only at impacted water bodies, M. tuberculata in sandy bottoms, and $P$. acuta attached to aquatic vegetation. The two species also colonize debris and/or man-made habitats.

Most of the records were done on the borders of Ilha Grande State Park (Fig. 1), except for the occurrence of A. fulica in Vila Dois Rios that is inside the park. On Praia do Sul Biological Reserve no invasive molluscs were found.

\section{Discussion}

Achatina fulica was widespread on villages of Ilha Grande (Figure 1 and Table 1), this is related to some features of this species like 


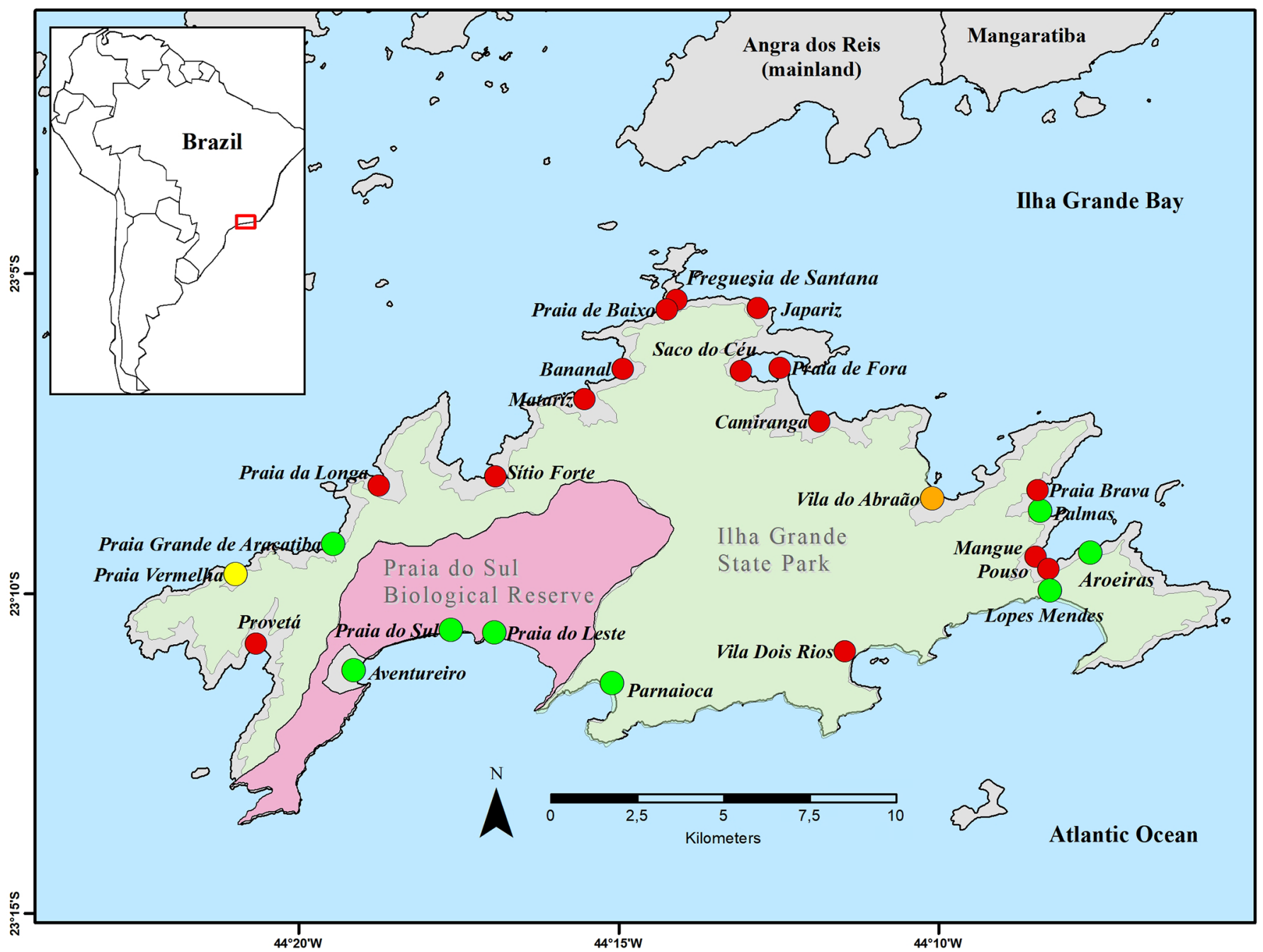

Figure 1. Distribution of Achatina fulica, Melanoides tuberculata, and Physa acuta in several villages of Ilha Grande. Red dots - Achatina fulica; Yellow dots Melanoides tuberculata and Physa acuta; Orange dots - A. fulica, M. tuberculata, and P. acuta; and Green dots - Invasive molluscs not found.

hermaphroditism, a high number of egg-laying per year (3 to 4), a high number of eggs per laying episode (200 to 400 ), and high adaptability to environmental conditions (Kosloski et al. 2002, Fischer \& Colley 2004). This species was probably dispersed on Ilha Grande attached to plants and other goods. The distribution of A. fulica on Ilha Grande seems to be restricted to anthropic and nearby areas of secondary forest. The species was so adapted to the anthropic environment of Ilha Grande that were found at gardens, walls, and streets. Fischer et al. (2008) stated that these urban areas offer resting sites and shelters against predation. Other authors already observed these environmental preferences of $A$. fulica (Colley \& Fischer 2009, Goldyn et al. 2017). The urban population can expand to nearby preserved forests (Raut \& Baker 2002, Fischer et al. 2006, Faraco 2011). Ilha Grande has a rich and diverse fauna of land snails (Haas 1953, Santos \& Monteiro 2001, Santos et al. 2010, Nunes \& Santos 2012, Cuezzo et al. 2018), but few occur in anthropic habitat, as preferred by A. fulica. However, the expansion of this species to preserved areas can increase the negative impacts of giant African land snail on the island; although some studies do not show so drastic outputs (Miranda et al. 2015, Miranda \& Pecora 2017, O’Loughlin \& Green 2017).
Melanoides tuberculata and $P$. acuta were restricted to two localities of Ilha Grande (Figure 1 and Table 1); the first record of $M$. tuberculata was in 2005 in Vila do Abraão (Santos et al. 2007) and P. acuta was in 2009 (Miyahira 2010) in the same locality. The population of $M$. tuberculata at Vila do Abraão was initially found in low numbers (Santos et al. 2007), therefore the population increased, also affecting negatively the native fauna (Braga et al. 2014). A subsequent record of M. tuberculata was done at Praia Vermelha (Gonçalves et al. 2012) in low numbers, probably indicating a recent introduction event, but the population still present on the following collecting events, probably indicating that population was established. This last locality is far from Vila do Abraão, therefore it is probable that this distribution extension was human-mediated (e.g. discharge of aquarium water with aquatic plants and snails). The aquatic species need more factors to be transported from one place to another, resulting in a slower dispersion, and narrow distributions on Ilha Grande. Another factor that possibly restricts the distribution of aquatic invaders is the morphology of the streams of Ilha Grande, usually small and running across small stretch before reaches the sea. Thus, these are streams with a low amount of nutrients and conductivity, preventing some newly introduced species to 
Oliveira JL. et al.

Table 1. The surveyed localities of Ilha Grande (Angra dos Reis, Rio de Janeiro, Brazil) and the date of first sighting of the three invasive species. N.F. $=$ Not Found.

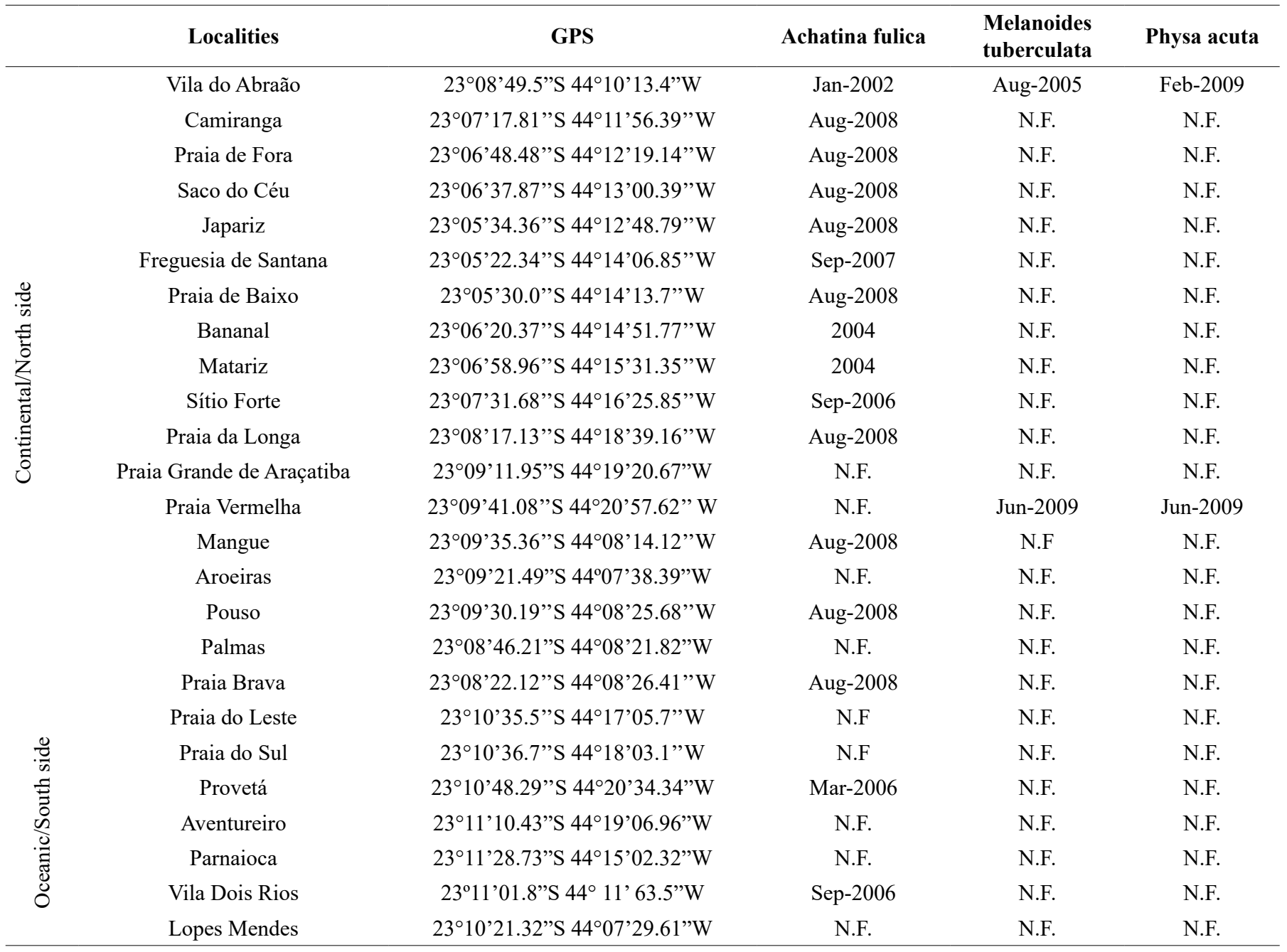

establish, and the dispersion of the exiting species to other places. The shell morphology of $M$. tuberculata is also different in both populations (Gonçalves et al. 2012). Physa acuta occurs at the same stream of $M$. tuberculata in Vila do Abraão and Praia Vermelha. This pulmonate snail was the last invader to be found on the island, and the impacts of this species over native fauna are scarce on the literature but cannot be neglected (Zukowski and Walker 2009). Gonçalves et al. (2014) reported Omalonyx matheroni (Potiez \& Michaud, 1835) in Villa do Abraão, but the introduction was not successful after periodic site visits (personal communication).

Most records of invasive molluscs in Ilha Grande were done on the North (or continental) side, facing the mainland. The two sides of the island present different environmental conditions (Nunes \& Santos 2012) but it is probably that observed distribution is not related to those environmental factors. On the North side, there is a large number of villages, and an easier movement of goods and people, thus increasing the likelihood of an introduction. Vila do Abraão, the village with a greater flow of people on the island, was the unique place where the three invasive species were found together. The two villages on the oceanic side that presented invasive species were Provetá and Vila Dois Rios. Provetá has the second-largest resident population of the island, and
Vila Dois Rios is connected by road to Vila do Abraão, one of the few roads on the island. Thus, the uncontrolled movement of people and goods seems to be important to understand and mitigate the spread of invasive molluscs on the island. This phenomenon was probably related to the explosive increase of touristic activities after the closing of Ilha Grande's Prison in 1994 (Prado 2003, Cadei et al. 2009), although a previously detailed inventory of non-marine molluses is not available. Haas (1953) pointed out some species of land and freshwater molluscs of Ilha Grande, and at that time, no non-native species were reported.

In addition to the tourism, the villages have experienced population growth and urban expansion, this can easily be noted at Vila do Abraão, Provetá, Bananal, Matariz, and Longa. In these villages there were always new buildings that demand a continuous trade of goods with the mainland, increasing the risk of unwanted introduction of species. Moreover, Ilha Grande doesn't have any kind of sanitary barrier; villagers and tourists can bring almost all kinds of animals and plants to the island. This lack of inspection can be a highway to the introduction of non-native species. The eight villages that do not present invasive species on Ilha Grande, also do not present a great touristic flow, except for Palmas.

Most records of invasive molluscs on Ilha Grande were out of restrictive conservation areas, except for A. fulica inside the Ilha Grande State Park. 
This record inside the park and those on the borders of conservation areas causes concern and calls attention to the need for inspection on the goods transported to the island. Those three invaders can expand their distribution on the island if the proper conditions were offered.

Another important consequence of the dispersion of invasive species is the introduction and dispersal of parasites (Font 2003). Oliveira \& Santos (2019) recorded cysts of the nematode Strongyluris Müller, 1894 in the pallial system of $A$. fulica collected in two populations from Ilha Grande: Vila do Abraão and Vila Dois Rios. This parasite has as final host lizards or rarely anurans (Vicente et al. 1993, Bursey et al. 2003), although A. fulica can also harbor other helminths that have the man as the final common host (Thiengo et al. 2007). Some habitat of this species, like coprophagy, can make easy the establishment of new cycles (Mead 1961, Fischer 2009, Goldyn et al. 2017). Ximenes et al. (2017) reported the occurrence of Centrocestus formosanus (Nishigori, 1924) in M. tuberculata in the population from Vila do Abraão, a helminth that has birds as the final hosts.

The occurrence of A. fulica, M. tuberculata, and $P$. acuta represent a risk to conservation of native species and public health, an effort to control those species must be done together with environmental education, public health, and environmental authorities to prevent and mitigate the spread of these invasive species on Ilha Grande.

\section{Acknowledgments}

Our gratitudes goes to Coordenação de Aperfeiçoamento de Pessoal de Nível Superior (CAPES), Conselho Nacional de Pesquisas (CNPq), and Fundação Carlos Chagas Filho de Amparo à Pesquisa do Estado do Rio de Janeiro (FAPERJ) for scholarships; to UERJ for Prociência grant to SBS, and PAPD (E-26/007/10662/2019) scholarship to LEML; to FAPERJ for financial support to SBS (E-26/110.430/2007, E-26/110.402/2010, E-26/111.573/2013, and E-26/010.0011639/2014-PPBIO Mata Atlântica); to Centro de Estudos Ambientais e Desenvolvimento Sustentável (CEADS, UERJ) for facilities; and to the two anonymous reviewers that contributed to the manuscript improvement. All samplings were carried out under legal authorizations (INEA 18/2007 and SISBIO 10812-1).

\section{Author Contributions}

Jaqueline L. de Oliveira: Substantial contribution in the concept and design of the study; Contribution to data collection; Contribution to data analysis and interpretation; Contribution to manuscript preparation; Contribution to critical revision, adding intelectual content.

Igor C. Miyahira: Substantial contribution in the concept and design of the study; Contribution to data collection; Contribution to data analysis and interpretation; Contribution to manuscript preparation; Contribution to critical revision, adding intelectual content.

Isabela Cristina B. Gonçalves: Contribution to data collection; Contribution to data analysis and interpretation; Contribution to manuscript preparation.

Renata F. Ximenes: Contribution to data collection; Contribution to data analysis and interpretation; Contribution to manuscript preparation.

Luiz Eduardo M. de Lacerda: Contribution to data collection; Contribution to data analysis and interpretation; Contribution to manuscript preparation.
Patrícia S. C. da Silva: Contribution to data collection; Contribution to data analysis and interpretation; Contribution to manuscript preparation.

Francielle C. Fonseca: Contribution to data collection; Contribution to data analysis and interpretation; Contribution to manuscript preparation.

Amilcar B. Barbosa: Contribution to data collection; Contribution to data analysis and interpretation; Contribution to manuscript preparation.

Gleisse Kelly M. Nunes: Contribution to data collection; Contribution to data analysis and interpretation; Contribution to manuscript preparation.

Sonia B. dos Santos: Substantial contribution in the concept and design of the study; Contribution to data collection; Contribution to manuscript preparation; Contribution to critical revision, adding intelectual content.

\section{Conflicts of interest}

The authors declare that they have no conflict of interest related to the publication of this manuscript.

\section{References}

BOLTOVSKOY, D. 2017. Traits and impacts of invasive species: Myths and evidences from the perspective of introduced freshwater mussels. Aquat Ecosyst Health 20(4): 334-343.

BRAGA, R.M.R., MIYAHIRA, I.C., LACERDA, L.E.M., GONÇALVES, I.C. $\&$ SANTOS, S.B. 2014. The influence of an invasive gastropod on the population dynamics of Pisidium punctiferum (Sphaeriidae) in an insular impacted stream in Rio de Janeiro, Brazil. In: PIZA, A.R.T., TALLARICO, L.F., INTROÍNI, G.O. \& SANTOS, S.B. (Orgs.) Medical and Applied Malacology Crossing Boundaries: Integrative Approaches to Malacology. Cambridge Scholars Publishing, Newcastle, p. 97-114.

BURSEY, C.R., GOLDBERG, S.R. \& TELFORD-JR, S.R. 2003. Strongyluris panamaensis sp. (Nematoda: Heterakidae) and other helminths from the lizard, Anolis biporcatus (Sauria: Polychrotidae), from Panama. J. Parasitol. 89(1):118-132.

CADEI, M.S., MARQUES, J.B. \& COLlARES, N.M. 2009. Educação Ambiental. In: BASTOS, M. \& CALLADO, C.H. (Orgs) O ambiente da Ilha Grande. UERJ/CEADS, Rio de Janeiro, p. 471-534.

CAllado, C.H., BARros, A.A.M., RiBAS, L.A., ALBARELlO, N., GAGLIARDI, R. \& JASCONE, C. 2009. Flora e cobertura vegetal. In: BASTOS, M. \& CALLADO, C.H. (Orgs) O ambiente da Ilha Grande. UERJ/CEADS, Rio de Janeiro, p. 91-162.

CLAVERO, M. \& GARCÍA-BERTHOU, E. 2005. Invasive species are a leading cause of animal extinctions. Trends Ecol. Evol. 20(3):110 http://dx.doi. org/10.1016/j.tree.2005.01.003.

COLLEY, E. \& FISCHER, M.L. 2009. Avaliação dos problemas enfrentados no manejo do caramujo gigante africano Achatina fulica (Gastropoda: Pulmonata) no Brasil. Zoologia 26(4):674-683. http://dx.doi.org/10.1590/ S1984-46702009000400012.

COWIE, R.H. 1998. Patterns of introduction of non-indigenous non-marine snails and slugs in the Hawaiian Islands. Biodivers. Conserv. 7:349-368.

COWIE, R.H., REGNIER, C., FONTAINE, B. \& BOUCHET P. 2017. Measuring the sixth extinction: what do mollusks tell us. Nautillus 131(1): 3-41.

CUEZZO, M.G., LIMA, A. \& SANTOS, S.B. 2018. Solaropsis brasiliana, anatomy, range extension and its phylogenetic position within Pleurodontidae (Mollusca, Gastropoda, Stylommatophora). An. Acad. Bras. Ciênc. 90(3): 2753-2765. http://dx.doi.org/10.1590/0001-3765201820170261.

FACON, B., MACHLINE, E., POINTIER, J.P. \& DAVID P. 2004. Variation in desiccation tolerance in freshwater snails and its consequences for invasion ability. Biol. Invasions 6: 283-293. 
FARACO, F.A. 2011. Controle de Achatina fulica Bowdich, $1822 \mathrm{em}$ unidades de conservação: um estudo de caso em Poço das Antas, Rio de Janeiro. In: FERNANDEZ, M.A., SANTOS, S.B., PIMENTA, A. \& THIENGO, S.C. (Eds). Tópicos em Malacologia: Ecos do XIX EBRAM. Sociedade Brasileira de Malacologia \& Technical Books Editora, Rio de Janeiro, p. 362-372.

FERNANDEZ, M.A., THIENGO, S.C. \& SIMONE, L.R.L. 2003. Distribution of the introduced freshwater snail Melanoides tuberculata (Gastropoda: Thiaridae) in Brazil. Nautilus. 117(3):78-82.

FISCHER, M. L. \& COLLEY, E. 2004. Diagnóstico da ocorrência do caramujo gigante africano Achatina fulica Bowdich, 1822 na APA de Guaraqueçaba, Paraná, Brasil. Estud Biol. 26: 43-50.

FISCHER, M. L. \& COLLEY, E. 2005. Espécie invasora em reservas naturais: caracterização da população de Achatina fulica Bowdich, 1822 (Mollusca - Achatinidae) na Ilha Rasa, Guaraqueçaba, Paraná, Brasil. Biota Neotrop. 5(1):127-144. https://doi.org/10.1590/S1676-06032005000100014

FISCHER, M.L., SIMIÃO, M.S., COLLEY, E., ZENNI, R.D., SILVA, D.A.T. \& LATOSKI, N. 2006. O caramujo exótico invasor na vegetação nativa em Morretes, PR: diagnóstico da população de Achatina fulica Bowdich, 1822 em um fragmento de Floresta Ombrófila Densa Aluvial. Biota Neotrop. 6(2): 1-5. http://dx.doi.org/10.1590/S1676-06032006000200029.

FISCHER, M. L.; COSTA, L. C. M.; NERING, I. S. 2008. Utilização de recursos no ambiente antrópico pelo caramujo gigante africano Achatina fulica Bowdich, 1822: subsídios para o manejo. Bioikos 22(2): 91-100.

FISCHER, M. L. 2009. Reações da espécie invasora Achatina fulica (Mollusca: Achatinidae) à fatores abióticos: perspectivas para o manejo. Zoologia 26 (3): 379-385. http://dx.doi.org/10.1590/S1984-46702009005000006.

FONT, W.F. 2003. The global spread of the parasites: what do Hawaiian streams tell us? BioScience. 53(11):1061-1067. http://dx.doi:10.1641/00063568(2003)053[1061:TGSOPW]2.0.CO.

GOLDYN, B., KACZMAREK, L., ROSZKOWSKA, M., GUAYASAMÍN, Z., PARULSKA-KSIAZKIEWICK, Z. \& CERDA, H. 2017. Urban ecology of invasive giant African snail Achatina fulica (Férussac) (Gastropoda: Achatinidae) on its first recorded sites in the Ecuadorian Amazon. Am. Mal. Bull. 35 (1): 59-64.

GONÇALVES, I.C.B., MIYAHIRA, I.C. \& SANTOS, S.B. 2012. Range extension of the alien freshwater snail Melanoides tuberculatus in Ilha Grande, Angra dos Reis, Rio de Janeiro, Brasil. Tentacle. 20:11-13.

GONÇALVES, I.C.B., MIYAHIRA, I.C. \& SANTOS, S.B. 2014. Accidental introductions of freshwater snails in an insular environment: A Case Study in Ilha Grande, Rio de Janeiro, Brasil, Tentacle. 22:13-16.

GRAEFF-TEIXEIRA, C. 2007. Expansion of Achatina fulica in Brazil and potential increased risk for angiostrongyliasis. T. Roy. Soc. Trop. Med. H. 101(8):743-744. http://dx.doi.org/ 10.1016/j.trstmh.2007.03.012.

GUTIÉRREZ, G., NÚÑEZ, D.E., VOGLER, V.R. \& RUMI, A. 2011. Invasion of the Argentinean Paranense rainforest by the giant African snail Achatina fulica. Am. Malacol. Bull. 29(1-2):135-137. http://dx.doi. org/10.4003/006.029.0205.

HAAS, F. 1953. Mollusks from Ilha Grande, Rio de Janeiro, Brazil. Fieldiana, Zool. 34:203-209.

KOSLOSKI, M.A. \& FISCHER, M.L. 2002. Primeira ocorrência de Achatina fulica (Bowdich, 1822) no litoral do estado do Paraná (Mollusca; Stylommatophora; Achatinidae). Estud Biol. 24: 65-69.

LEITE, O.H.M., HIGAKI, Y., SERPENTINI, S.L.P., CARVALHO, A.S., AMATO, N.V., TORRES, D.M.A., DIAS, R.M.D.S. \& CHIEFFI, P.P. 1989. Infecção por Clonorchis sinensis em imigrantes asiáticos no Brasil. Tratamento com praziquantel. Rev. Inst. Med. Trop. SP. 31(6):416-422. http://dx.doi.org/10.1590/S0036-46651989000600008.

LEME, J.L.M. 1966. Sobre a ocorrência do subgênero Physella no Brasil, e descrição de uma nova espécie (Mollusca, Gastropoda). Pap. avulsos zool. 19(27):269-278

LOCKWOOD, J.L., HOOPES, M.F. \& MARCHETTI, M.P. 2005. Invasion Ecology. John Wiley \& Sons, 312p.

MEAD, A.R. The giant African snail: a problem in economic malacology. Chicago: University of Chicago Press, 1961. 257 p.
MIRANDA, M. \& PECORA, I. 2017. Conservation implications of behavioral interactions between the Giant African Snail and a Native Brazilian species. Ethol. Ecol. Evol. 29(3):209-217.

MIRANDA, M.S., FONTENELLE, J.H. \& PECORA, I.L. 2015. Population structure of a native and an alien species of snail in an urban area of the Atlantic Rainforest. J. Nat. Hist. 49(1-2):19-35.

MIYAHIRA, I.C., LACERDA, L.E.M. \& SANTOS, S.B. 2010. How many species are introduced every day? Some insights from a tropical insular stream in Brasil. Tentacle 18:30- 32.

MIYAHIRA, I.C., PEREIRA, L.S. \& SANTOS, L.N. 2020. Non-native freshwater molluscs in the Neotropics: what can be learned from Brazilian reservoirs? Aquatic Invasions 15 (in press).

NUNES, G.K.M. \& SANTOS, S.B. 2012. Environmental factors affecting the distribution of land snails in the Atlantic Rain Forest of Ilha Grande, Angra dos Reis, RJ, Brazil. Braz. J. Biol. 72(1):79-86.

O'LOUGHLIN, L.S. \& GREEN, P.T. 2017. The secondary invasion of giant African land snail has little impact on litter or seedling dynamics in rainforest. Austral Ecol. 42:819-830.

OLIVEIRA, J.L. \& SANTOS, S.B. 2019. Distribution of cysts of Strongyluris sp. (Nematoda) in the pallial system of Achatina fulica Bowdich, 1822 from Vila Dois Rios and Vila do Abraão, Ilha Grande, Angra dos Reis, Rio de Janeiro. Braz. J. Biol. 79(1):38-44. http://dx.doi.org/10.1590/1519-6984.173449.

OLIVEIRA, A.P.M., TORRES, E.J.L., MALDONADO, J.R.A., ARAÚJO, J.L.B., FERNANDEZ, M.F. \& THIENGO, S.C. 2010. Achatina fulica como hospedeiro intermediário de nematódeos de interesse médico-veterinário em Goiás, Brasil. Rev. patol. trop. 39(3):199-210. http://dx.doi.org/10.5216/ rpt.v39i3.12211.

PARAENSE, W.L. \& POINTIER, J.P. 2003. Physa acuta Draparnaud, 1805 (Gastropoda: Physidae): a study of topotypic specimens. Mem. Inst. Oswaldo Cruz. 98(4):513-517.

PIMENTEL, D., ZUNINGA, R. \& MORRISON, D. 2005. Update on the environmental and economic costs associated with alien-invasive species in the United States. Ecol Econ 52: 273-288.

PINTO, H.A. \& MELO, A.L. 2011. A checklist of trematodes (Platyhelminthes) transmitted by Melanoides tuberculata (Mollusca: Thiaridae). Zootaxa. 2799:15-28

PRADO, R.M. 2003. Espécies exóticas somos nós: Reflexão a propósito do ecoturismo na Ilha Grande. Horiz. antropol. 9(20): 205-224.

PYŠEK, P., BLACKBURN, T.M., GARCÍA-BERTHOU, E., PERGLOVÁ, I. \& RABITSCH, W. 2017. Displacement and Local Extinction of Native and Endemic Species. In: VILÀ, M. \& HULME, P. (Eds) Impact of Biological Invasions on Ecosystem Services. Invading Nature - Springer Series in Invasion Ecology 1 12. Springer, Cham.

RAUT, S.K.; BAKER, G.M. 2002. Achatina fulica Bowdich and other Achatinidae as pest in Tropical agriculture In: BAKER, G. M. (Ed). Mollusc as Crop Pests. Calcutá: CAB International, p. 55-114.

SANTOS, S.B. \& MONTEIRO, D.P. 2001. Composição de gastrópodes terrestres em duas áreas do Centro de Estudos Ambientais e Desenvolvimento Sustentado (CEADS), Vila Dois Rios, Ilha Grande, Rio de Janeiro, Brasil - um estudo-piloto. Rev. Bras. Zool. 18 (supl.1): 181-190. http://dx.doi. org/10.1590/S0101-81752001000500014

SANTOS, S.B., MONTEIRO, D.P. \& THIENGO, S.C. 2002. Achatina fulica (Mollusca, Achatinidae) na Ilha Grande, Angra dos Reis, Rio de Janeiro: implicações para a saúde ambiental. Biociências 10(2):159-162.

SANTOS, S.B., MIYAHIRA, I.C. \& LACERDA, L.E.M. 2007. First record of Melanoides tuberculata (Müller, 1774) and Biomphalaria tenagophila (d'Orbigny, 1835) on Ilha Grande, Rio de Janeiro, Brazil. Biota Neotrop. 7(3):361-364. http://www.biotaneotropica.org.br/v7n3/pt/abstract?shortcommunication+bn01307032007.

SANTOS, S.B., RODRIGUES, C.L., NUNES, G.K.M., BARBOSA, A.B., LACERDA, L.E.M., MIYAHIRA, I.C., VIANA, T.A., OLIVEIRA. J.L., FONSECA, F.C. \& SILVA, P.S.C. 2010. Estado do conhecimento da fauna de invertebrados não marinhos da Ilha Grande (Angra dos Reis, RJ). Oecologia Australis 14(2):504-549. 
SANTOS, S.B., THIENGO, S.C., FERNANDEZ, M.A., MIYAHIRA, I.C., GONÇALVES, I.C., XIMENES, R.F., MANSUR, M.C.D. \& PEREIRA, D. 2012. Espécies de moluscos límnicos invasores no Brasil. In: MANSUR. M.C.D., SANTOS, C.P., PEREIRA, D., PAZ, I.C.P., ZURITA, M.L.L., RODRIGUEZ, M.T.R., NEHRKE, M.V. \& BERGONCI, P.E.A. (Orgs). Moluscos Límnicos Invasores no Brasil: Biologia, Prevenção e Controle. Redes Editora, Porto Alegre, 25-49pp.

SANTOS, S.B., THIENGO, S.C., FERNANDEZ, M.A., MIYAHIRA, I.C., SILVA, E.F., LOPES, B.G., GONÇALVES, I.C., XIMENES, R.F. \& LACERDA, L.E.M. 2016. Moluscos Límnicos- Gastrópodes. In: LATINI, A.O., RESENDE, D.C., POMBO, V.B. \& CORADIN, L. (Orgs.) Espécies exóticas invasoras de águas continentais no Brasil, MMA (Série Biodiversidade), Brasília, 221-248.

TAYLOR, D.W. 2003. Introduction to Physidae (Gastropoda: Hygrophila); biogeography, classification, morphology. Rev. Biol. Trop. 51:1-263.

THIENGO, S.C., FARACO, F.A., SALGADO, N.C., COWIE, R. \& FERNANDEZ, M.A. 2007. Rapid spread of an invasive snail in South America: the giant African snail, Achatina fulica, in Brasil. Biol. Invasions 9(6):693-702. http://dx.doi.org/10.1007/s10530-006-9069-6.

THIENGO, S.C., FERNANDEZ, M.A., TORRES, E.J.L., COELHO, P.M. \& LANFREDI, R.M. 2008. First record of a nematode Metastrogyloidea (Aelurostrongylus abstrusus larvae) in Achatina (Lissachatina) fulica (Mollusca, Achatinidae) in Brazil. Journal of Invertebrate Pathology 98(1):34-39. http://dx.doi.org/10.1016/j.jip.2007.10.010.

TOMIYAMA, K. 2002. Age dependency of sexual role and reproductive ecology in a simultaneously hermaphroditic land snail, Achatina fulica (Stylommatophora: Achatinidae). Venus 60(4): 273 - 283.
VAZ, J.F., TELES, H.M.S., CORREA, M.A. \& LEITE, S.P.S. 1986. Ocorrência no Brasil de Thiara (Melanoides) tuberculata (Muller, 1774) (Gastropoda, Prosobranchia), primeiro hospedeiro intermediário de Clonorchis sinensis (Cobbold, 1875) (Trematoda, Plathyhelmintes). Rev. Saude Publ. 20(4):318e22. http://dx.doi.org/10.1590/S0034-89101986000400008.

VICENTE, J.J., RODRIGUES, H.O., GOMES, D.C. \& PINTO, R.M. 1993. Nematóides do Brasil. Parte III: Nematóides de répteis. Rev. Bras. Zool. 10(1):19-168.

WEIR, S.M. \& SALICE C.J. 2012. High tolerance to abiotic stressors and invasion success of the slow growing freshwater snail, Melanoides tuberculatus. Biol. Invasions 14: 385-394.

XIMENES, R.F., GONÇALVES, I.C.B., MIYAHIRA, I.C., PINTO, H.A., MELO, A.L. \& SANTOS, S.B. 2017. Centrocestus formosanus (Trematoda Heterophyidae) in Melanoides tuberculata (Gastropoda: Thiaridae) from Vila do Abraão, Ilha Grande, Rio de Janeiro, Brazil. Braz. J. Biol. 77(2):318-322.

ZUKOWSKI, S. \& WALKER, K.F. 2009. Freshwater snails in competition: alien Physa acuta (Physidae) and native Glyptophysa gibbosa (Planorbidae) in the River Murray, South Australia. Mar. Freshwater Res. 60:999-1005.

Received: $15 / 06 / 2020$

Revised: $22 / 07 / 2020$

Accepted: 29/07/2020

Published online: 02/09/2020 